\title{
Pengetahuan Perpajakan, Sanksi Pajak Kesadaran Wajib Pajak dan Kepatuhan WPOP Sektor UMKM
}

\author{
Ni Luh Gede Santhi Kartikasari ${ }^{1}$ \\ Fakultas Ekonomi dan Bisnis \\ Universitas Udayana, Indonesia
}

\author{
I Ketut Yadnyana ${ }^{2}$ \\ Fakultas Ekonomi dan Bisnis \\ Universitas Udayana, Indonesia
}

Surel : santhikartikasari73@gmail.com

\section{ABSTRAK}

Tujuan penelitian ini adalah untuk menguji pengaruh pengetahuan perpajakan, sanksi pajak, dan kesadaran wajib pajak terhadap kepatuhan wajib pajak orang pribadi sektor UMKM. Sebanyak 98 wajib pajak orang pribadi sektor UMKM dipilih menjadi responden dengan menggunakan rumus slovin. Metode penentuan sampel pada penelitian ini adalah accidental sampling dan teknik analisis data penelitian ini menggunakan analisis regresi linier berganda. Hasil penelitian ini menunjukkan bahwa pengetahuan perpajakan, sanksi pajak dan kesadaran wajib pajak berpengaruh positif terhadap kepatuhan wajib pajak UMKM.

Kata Kunci: Pengetahuan Perpajakan; Sanksi Pajak; Kesadaran Wajib Pajak; Kepatuhan Wajib Pajak UMKM.

\section{Knowledge of Taxation, Tax Sanctions, Taxpayer} Awareness and WPOP Compliance for the UMKM Sector

\begin{abstract}
The purpose of this study was to examine the effect of tax knowledge, tax sanctions, and awareness of taxpayers on MSME sector taxpayer compliance. A total of 98 individual taxpayers of the MSME sector were selected as respondents using the Slovin formula. The sampling method in this study is accidental sampling and the data analysis technique of this study uses multiple linear regression analysis. The results of this study indicate that tax knowledge, tax sanctions and awareness of taxpayers have a positive effect on tax compliance of SMEs.
\end{abstract}

Keywords: $\quad$ Time Budget Pressure; Pressure Management; Locus of Control; Dysfunctional Behavior; Auditor Performance.

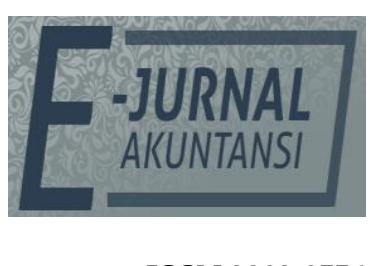

e-ISSN 2302-8556

Vol. 31 No. 4

Denpasar, April 2021

Hal. 925-936

DOI:

10.24843/EJA.2021.v31.i04.p10

PENGUTIPAN:

Kartikasari, N.L.G.S., \&

Yadnyana, I K. (2021).

Pengetahuan Perpajakan, Sanksi Pajak Kesadaran Wajib Pajak dan Kepatuhan WPOP Sektor UMKM. E-Jurnal Akuntansi, 31(4), 925-936

RIWAYAT ARTIKEL: Artikel Masuk: 2 Januari 2020 Artikel Diterima: 23 Februari 2020

Artikel dapat diakses : https://ojs.unud.ac.id/index.php/Akuntansi/index 


\section{PENDAHULUAN}

Pada tahun 2018, masalah rendahnya kepatuhan pajak di Badung Utara masih dialami hingga saat ini. Jumlah WP OP UMKM yang tercatat di KPP Pratama Badung Utara per Desember 2018 mencapai 12.995 wajib pajak orang pribadi UMKM. Kondisi tersebut dapat dicantumkan dalam data wajib pajak orang pribadi UMKM pada Tabel 1.

Tabel 1. Tingkat Kepatuhan Wajib Pajak Orang Pribadi sektor UMKM dalam Pelaporan SPT di KPP Pratama Badung Utara Tahun 2015-2018

\begin{tabular}{lcccc}
\hline Tahun & $\begin{array}{c}\text { WP OP } \\
\text { UMKM } \\
\text { Terdaftar }\end{array}$ & $\begin{array}{c}\text { WP OP } \\
\text { UMKM } \\
\text { Wajib Lapor }\end{array}$ & $\begin{array}{c}\text { WP OP UMKM } \\
\text { Lapor }\end{array}$ & Kepatuhan (\%) \\
\hline 2015 & 10.014 & 3.828 & 2.406 & 62,85 \\
2016 & 11.000 & 4.067 & 2.624 & 64,73 \\
2017 & 11.805 & 4.692 & 3.435 & 73,21 \\
2018 & 12.995 & 5.178 & 3.941 & 76,11 \\
\hline
\end{tabular}

Sumber: KPP Pratama Badung Utara, 2019

Berdasarkan Tabel 1, dapat dilihat bahwa tingkat kepatuhan wajib pajak orang pribadi sektor UMKM dalam pelaporan SPT masih belum maksimal dari tahun 2015-2018. Berdasarkan data yang diperoleh, tingkat kepatuhan wajib pajak tahun 2015 berada pada persentase 62,85\%, kemudian mengalami sedikit peningkatan pada tahun 2016 yaitu berada pada persentase $64,73 \%$. Pada tahun 2017, kembali terjadi kenaikan hingga mencapai kisaran 73,21\%. Pada tahun 2018 kembali mengalami sedikit peningkatan yaitu berada pada persentase $76,11 \%$. Presentase kepatuhan pajak telah mengalami peningkatan hingga tahun 2018. Meningkatkan tingkat kepatuhan wajib pajak merupakan masalah yang paling serius bagi pembuat kebijakan tersebut. Peningkatan jumlah UMKM tersebut tidak sejalan dengan kesadaran wajib pajak UMKM dalam memenuhi kewajibannya untuk membayar pajak. Data Penerimaan Wajib Pajak Orang Pribadi sektor UMKM KPP Pratama Badung Utara dapat dilihat pada Tabel 2.

Tabel 2. Data Penerimaan Wajib Pajak Orang Pribadi sektor UMKM KPP Pratama Badung Utara Tahun 2015-2018

\begin{tabular}{cc}
\hline Tahun & Realisasi \\
\hline 2015 & 27.126 .729 .458 \\
2016 & 42.346 .072 .546 \\
2017 & 43.894 .542 .007 \\
2018 & 43.777 .507 .016 \\
\hline
\end{tabular}

Sumber: KPP Pratama Badung Utara, 2019

Berdasarkan data pada Tabel 2, dapat dilihat bahwa realisasi penerimaan pajak dari wajib pajak orang pribadi sektor UMKM terus meningkat dari tahun 2015-2017 namun kembali sedikit menurun pada tahun 2018. Rendahnya kepatuhan wajib pajak UMKM tersebut mendorong pemerintah untuk membuat peraturan baru, mulai tanggal 1 Juli 2018 tarif PPh Final UMKM resmi turun dari $1 \%$ menjadi $0,5 \%$. Perubahan tarif PPh Final UMKM tersebut tercantum dalam PP No. 23 Tahun 2018. Penerapan PPh Final 0,5\% memberikan kemudahan bagi wajib pajak untuk melaksanakan kewajiban perpajakan. Sebab, perhitungan pajak menjadi sederhana yakni 0,5\% dari peredaran bruto/omzet.

Peraturan ini sejatinya dibuat untuk memudahkan wajib pajak dalam melakukan perhitungan, penyetoran, dan pelaporan kewajiban perpajakannya. 
Selain untuk memberikan kemudahan, pemberlakuan peraturan ini merupakan usaha pemerintah dalam meningkatkan kepatuhan wajib pajak. Menurut (Fuadi \& Mangoting, 2013) kepatuhan wajib pajak dapat dipengaruhi oleh dua faktor yaitu faktor eksternal dan faktor internal. Faktor eksternal adalah faktor yang berasal dari luar diri wajib pajak, seperti pengetahuan perpajakan dan sanksi pajak. Berbeda dengan faktor eksternal, faktor internal merupakan faktor yang berasal dari diri wajib pajak sendiri dan berhubungan dengan karakteristik individu yang menjadi pemicu dalam menjalankan kewajiban perpajakan, seperti kesadaran wajib pajak.

Pengetahuan perpajakan merupakan salah satu faktor yang melatarbelakangi tingkat kepatuhan wajib pajak dalam membayar pajak diantaranya pengetahuan wajib pajak mengenai peraturan perpajakan. Pengetahuan perpajakan adalah informasi pajak yang dapat digunakan wajib pajak sebagai dasar untuk bertindak, mengambil keputusan dan untuk menempuh arah atau strategi tertentu sehubungan dengan pelaksanaan hak dan kewajibannya di bidang perpajakan. Wajib pajak memperoleh pengetahuan tentang perpajakan melalui fiskus. Wajib Pajak akan cenderung tidak menjadi patuh ketika tidak memahami peraturan perpajakan (Julianti, 2014). Hasil penelitian sebelumnya menyebutkan bahwa pengetahuan perpajakan berpengaruh terhadap kepatuhan pajak UMK (Mintje, 2016), dan (Oladipupo \& Obazee, 2016). Hal ini perlu dikaji lagi karena penelitian oleh (Julianto, 2016) menyatakan bahwa pengetahuan perpajakan tidak berpengaruh terhadap kepatuhan pajak UMKM.

Di Indonesia, pengetahuan wajib pajak masih cukup rendah (Wiranatha \& Rasmini, 2017). Padahal Kantor Pelayanan Pajak (KPP) sudah menyediakan buku petunjuk dan tempat pelayanan terpadu yang selalu sedia setiap saat melayani wajib pajak dengan segala kepentingan dan permasalahannya. Salah satu upaya yang dapat dilakukan untuk menyikapi masalah tersebut adalah dengan mengadakan sosialisasi Kepatuhan Wajib Pajak Perorangan dan Badan dalam membayar pajak. Upaya ini bertujuan untuk memberikan edukasi, pengetahuan dan pemahaman tentang perpajakan, baik kepada wajib pajak maupun masyarakat, sehingga diharapkan akan meningkatkan kesadaran wajib pajak dan ketertiban dalam membayar pajak.

Peningkatan jumlah UMKM harus diimbangi dengan kesadaran wajib pajak UMKM untuk melaksanakan kewajiban perpajakannya. Masruroh \& Zulaikha (2013) menjelaskan bahwa kesadaran dan kedisiplinan dari masyarakat sangat diperlukan untuk memahami dan mematuhi kewajiban perpajakan, Pemahaman tersebut meliputi pengisian Surat Pemberitahun (SPT), perhitungan pajak, penyetoran pajak (pembayaran), pelaporan atas pajaknya. Sistem pemungutan pajak merupakan sebuah mekanisme yang digunakan untuk menghitung besarnya pajak yang harus dibayar wajib pajak ke negara. Hasil penelitian (Sasmita, 2015) \& (Mintje, 2016) menyebutkan bahwa kesadaran wajib pajak berpengaruh terhadap kepatuhan pajak UMKM. Hal ini perlu dikaji lagi karena penelitian oleh (Yusro, 2014) menyatakan bahwa kesadaran wajib pajak tidak berpengaruh terhadap kepatuhan pajak UMKM.

Di Indonesia, berlaku 3 jenis sistem pemungutan pajak, yaitu Self Assessment System, Official Assessment System, Withholding Assessment System. Self Assessment 
System merupakan sistem pemungutan pajak yang membebankan penentuan besaran pajak yang perlu dibayarkan oleh wajib pajak yang bersangkutan. Sistem pemungutan pajak self assessment system, tentunya menuntut adanya peran serta aktif dari masyarakat dalam memenuhi kewajibannya membayar pajak. Selain itu dibutuhkan pula kepatuhan yang tinggi dari wajib pajak, yaitu kepatuhan dalam pemenuhan kewajiban perpajakan yang sesuai dengan kebenarannya. (Supadmi, 2010) menyatakan perubahan sikap (kesadaran) warga masyarakat untuk membayar pajak secara sukarela (voluntary compliance) merupakan misi dan konsekuensi diterapkannya sistem Self Assessment.

Pada kenyataannya, kepatuhan bukan merupakan tindakan yang mudah untuk direalisasikan oleh setiap wajib pajak. Kebanyakan dari masyarakat memiliki kecenderungan untuk dapat meloloskan diri dari kewajibannya membayar pajak dan melanggar hukum. Selain dengan self assessment system, strategi pemerintah untuk meningatkan penerimaan pajak dan sekaligus meningkatkan Kepatuhan Wajib Pajak dalam membayar pajak, pemerintah juga menerapkan Sanksi Perpajakan.

Sanksi tersebut yaitu setiap wajib pajak yang melanggar ketentuan peraturan perundang-undangan perpajakan dikenai sanksi administrasi, sanksi pidana, atau keduanya. Sanksi administrasi yang dikenakan pada pelanggar pajak berupa bunga, denda, atau kenaikan. Muliari \& Setiawan (2011) melakukan penelitian mengenai kepatuhan pelaporan Wajib Pajak orang pribadi di KPP Pratama Denpasar Timur yang diukur melalui dua variabel bebas yaitu persepsi tentang sanksi perpajakan dan kesadaran wajib pajak. Hasil penelitian tersebut menyimpulkan bahwa variabel persepsi tentang sanksi perpajakan memiliki pengaruh positif terhadap kepatuhan pelaporan Wajib Pajak. Wajib Pajak akan memenuhi kewajiban perpajakannya apabila memandang bahwa sanksi perpajakan akan lebih banyak merugikannya (Jatmiko, 2006). Penelitian oleh (Yadnyana, 2009) juga menyimpulkan hal yang serupa yaitu sikap Wajib Pajak terhadap kewajiban perpajakan yang berupa sanksi pajak memiliki pengaruh positif terhadap kepatuhan Wajib Pajak. Hal ini perlu di kaji lagi karena penelitian oleh Lazuardini \& Susyanti (2018) menyatakan bahwa sanksi pajak berpengaruh negatif dan tidak signifikan terhadap kepatuhan pajak UMKM.

Usaha Mikro, kecil dan menengah (UMKM) memberi kontribusi yang signifikan dalam perekonomian nasional. Banyaknya jumlah unit UMKM di Indonesia seharusnya juga tercermin pada penerimaan pajak. Namun, penerimaan pajak didominasi oleh Wajib Pajak badan yang jumlahnya kurang dari 1\%, dimana sisanya adalah Wajib Pajak yang bergerak di bidang UMKM (Fuadi \& Mangoting, 2013). Bagi pelaku UMKM, pajak masih dilihat sebagai beban, yang sebisa mungkin harus dihindari. Pemerintah Indonesia perlu memperhatikan sektor UMKM secara serius. Peranan UMKM dalam perekonomian harus ikut diperhitungkan dalam proses merencanakan suatu kebijakan di bidang perpajakan. Banyaknya pelaku usaha UMKM bila diperhatikan secara seksama merupakan potensi yang akan berdampak pada peningkatan perilaku kepatuhan pajak. Berdasarkan penjabaran latar belakang tersebut, maka peneliti ingin meneliti pengaruh pengetahuan perpajakan, kesadaran wajib pajak dan sanksi perpajakan terhadap kepatuhan wajib pajak orang pribadi UMKM yang dilakukan di KPP Pratama Badung Utara, Bali. 
Berdasarkan hasil penelitian Wiranatha \& Rasmini (2017) menunjukkan bahwa pengetahuan perpajakan berpengaruh positif pada kepatuhan membayar pajak wajib pajak badan sektor UMKM di Kabupaten Jembrana. (Mintje, 2016) dalam penelitiannya juga menyimpulkan bahwa pengetahuan wajib pajak berpengaruh secara signifikan terhadap kepatuhan wajib pajak pemilik UMKM yang terdaftar di KPP Pratama Kota Manado.

$\mathrm{H}_{1}$ : Pengetahuan perpajakan berpengaruh positif terhadap kepatuhan wajib pajak orang pribadi sektor UMKM.

Terdapat undang-undang yang mengatur ketentuan umum serta tata cara perpajakan, dimana wajib pajak harus melaksanakan peraturan tersebut. Jika peraturan tidak dilaksanakan dengan baik atau bahkan dilanggar maka harus ada sanksi yang dikenakan untuk menimbulkan efek jera pada wajib pajak. Untuk mencegah ketidakpatuhan serta untuk mendorong wajib pajak untuk memenuhi kewajiban perpajakannya maka haruslah diberikan sanksi yang tegas dalam rangka untuk memajukan keadilan dan efektivitas system.

Berdasarkan hasil penelitian Imaniati (2016) menunjukkan bahwa sanksi perpajakan berpengaruh positif dan signifikan terhadap kepatuhan wajib pajak UMKM di Kota Yogyakarta. Sasmita (2015) dan Cahyani \& Noviari (2019) dalam penelitiannya juga menyimpulkan bahwa sanksi Perpajakan berpengaruh positif terhadap kepatuhan WP UMKM.

$\mathrm{H}_{2}$ : Sanksi Pajak berpengaruh positif terhadap kepatuhan wajib pajak orang pribadi sektor UMKM.

Kesadaran merupakan hal yang penting agar seseorang melaksanakan kewajibannya dengan baik. Theory of Planned Behavior pada faktor behavioral beliefs menjelaskan perilaku wajib pajak dalam memenuhi kewajiban perpajakannya. Ketika wajib pajak ingin membayar pajak, maka ia memiliki keyakinan mengenai manfaat yang akan diperoleh dari pajak yang dibayarnya. Semakin tinggi tingkat kesadaran wajib pajak, maka pemahaman dan pelaksanaan kewajiban perpajakan semakin baik sehingga dapat meningkatkan kepatuhan (Dewinta, 2012). Sasmita (2015) dalam penelitiannya menyimpulkan bahwa terdapat pengaruh secara signifikan dan positif antara Kesadaran Wajib Pajak terhadap Kepatuhan Wajib Pajak.

$\mathrm{H}_{3}$ : Kesadaran wajib pajak berpengaruh positif terhadap kepatuhan wajib pajak orang pribadi sektor UMKM.

\section{METODE PENELITIAN}

Penelitian ini dilaksanakan di KPP Pratama Badung Utara. Alasan peneliti melakukan penelitian di KPP Pratama Badung Utara karena Kabupaten Badung merupakan salah satu kabupaten di Provinsi Bali yang aktif pada sektor pertanian dan pariwisata. Melihat banyaknya UMKM dan kurangnya kepatuhan Wajib Pajak dalam memenuhi kewajibannya membuat peneliti tertarik untuk meneliti faktor-faktor yang mempengaruhi kepatuhan Wajib Pajak Pribadi UMKM di Kabupaten Badung, Kecamatan Badung Utara.

Populasi yang dipilih dalam penelitian ini adalah seluruh Wajib Pajak Orang Pribadi sektor UMKM dengan peredaran bruto kurang atau sama dengan Rp 4,8 milyar pertahun yang terdaftar pada KPP Pratama Badung Utara. Populasi dalam penelitian ini adalah sejumlah 3.941 Wajib Pajak Orang Pribadi sektor UMKM 
yang terdaftar di KPP Pratama per Desember 2018. Berikut pada Tabel 1, disajikan daftar klasifikasi jumlah wajib orang pribadi sektor UMKM pada tahun 2015-2018.

Analisis regresi berganda digunakan untuk melihat pengaruh beberapa variabel independen terhadap variabel dependen. Secara umum formulasi dari regresi linear berganda dapat di tulis sebagai berikut.

$$
\text { Y }=\alpha+\beta_{1} X_{1}+\beta_{2} X_{2}+\beta_{3} X_{3}+\varepsilon \text {. }
$$

Keterangan :

$\mathrm{Y} \quad=$ Kepatuhan Wajib Pajak

a $\quad=$ Konstanta

$\beta_{1}, \beta_{2}, \beta_{3}=$ Koefisien Regresi dari variabel independen

e $\quad=$ error term

$\mathrm{X}_{1} \quad=$ Pengetahuan Perpajakan

$\mathrm{X}_{2} \quad=$ Sanksi Pajak

$\mathrm{X}_{3} \quad=$ Kesadaran Wajib Pajak

\section{HASIL DAN PEMBAHASAN}

Statistik deskriptif dalam penelitian ini digunakan untuk memberikan informasi mengenai karakteristik variabel-variabel penelitian, antara lain nilai minimum, maksimum, rata-rata, simpangan baku (standar deviasi) dengan $\mathrm{N}$ adalah banyaknya responden penelitian. Hasil statistik deskriptif dapat dilihat pada Tabel 3, sebagai berikut.

\section{Tabel 3. Hasil Uji Statistik Deskriptif}

\begin{tabular}{lcllll}
\hline Variabel & $\mathrm{N}$ & Minimum & Maximum & Mean & $\begin{array}{l}\text { Std. } \\
\text { Deviation }\end{array}$ \\
\hline $\begin{array}{l}\text { Pengetahuan Perpajakan } \\
(X 1)\end{array}$ & 98 & 12.00 & 20.00 & 16.53 & 2.061 \\
Sanksi Pajak (X2) & 98 & 13.00 & 20.00 & 16.80 & 1.836 \\
$\begin{array}{l}\text { Kesadaran Wajib Pajak } \\
\begin{array}{l}\text { X3) } \\
\text { Kepatuhan Wajib Pajak }\end{array}\end{array}$ & 98 & 8.00 & 16.00 & 13.77 & 1.738 \\
UMKM (Y) & 13.00 & 24.00 & 20.29 & 2.529 \\
\hline
\end{tabular}

Sumber: Data Penelitian, 2019

Variabel pengetahuan perpajakan $\left(X_{1}\right)$ memiliki nilai minimum sebesar 12,00 dan nilai maksimum sebesar 20,00. Nilai rata-rata untuk variabel pengetahuan perpajakan adalah sebesar 16,53 yang berarti rata-rata pengetahuan perpajakan pada sampel amatan dalam penelitian ini bernilai 16,53. Standar deviasi sebesar 2,061 yang memiliki makna bahwa terjadi penyimpangan nilai pengetahuan perpajakan pada nilai rata-ratanya sebesar 2,061.

Variabel sanksi pajak $\left(X_{2}\right)$ memiliki nilai minimum sebesar 13,00 dan nilai maksimum sebesar 20,00. Nilai rata-rata untuk variabel sanksi pajak adalah sebesar 16,80 yang berarti rata-rata sanksi pajak pada sampel amatan dalam penelitian ini bernilai 16,80 . Standar deviasi sebesar 1,836 yang memiliki makna bahwa terjadi penyimpangan nilai sanksi pajak pada nilai rata-ratanya sebesar 1,836 .

Variabel kesadaran wajib pajak $\left(X_{3}\right)$ memiliki nilai minimum sebesar 8,00 dan nilai maksimum sebesar 16,00. Nilai rata-rata untuk variabel kesadaran wajib pajak adalah sebesar 13,77 yang berarti rata-rata kesadaran wajib pajak pada 
sampel amatan dalam penelitian ini bernilai 13,77. Standar deviasi sebesar 1,738 yang memiliki makna bahwa terjadi penyimpangan nilai kesadaran wajib pajak pada nilai rata-ratanya sebesar 1,738.

Variabel kepatuhan wajib pajak (Y) UMKM memiliki nilai minimum sebesar 13,00 dan nilai maksimum sebesar 24,00. Nilai rata-rata untuk variabel kepatuhan wajib pajak adalah sebesar 20,29 yang berarti rata-rata kepatuhan wajib pajak pada sampel amatan dalam penelitian ini bernilai 20,29. Standar deviasi sebesar 2,529 yang memiliki makna bahwa terjadi penyimpangan nilai kepatuhan wajib pajak pada nilai rata-ratanya sebesar 2,529.

Perhitungan koefisien regresi linear berganda dilakukan dengan analisis regresi melalui SPSS 24 for Windows, diperoleh hasil yang ditunjukkan pada Tabel 4, sebagai berikut.

Tabel 4. Hasil Uji Regresi Linier Berganda

\begin{tabular}{lllll}
\hline Variabel & $\begin{array}{l}\text { Unstandardized } \\
\text { Beta }\end{array}$ & Std. Error & T hitung & Sig. uji t \\
\hline (Constant) & 1.668 & 2.562 & 0.651 & 0.517 \\
Pengetahuan Pajak & 0.423 & 0.105 & 4.044 & 0.000 \\
Sanksi Pajak & 0.404 & 0.123 & 3.301 & 0.001 \\
Kesadaran Wajib Pajak & 0.351 & 0.125 & 2.807 & 0.006 \\
\hline
\end{tabular}

Sumber: Data Penelitian, 2019

Berdasarkan hasil analisis regresi linear berganda seperti yang disajikan pada Tabel 4, maka dapat dibuat persamaan regresi sebagai berikut.

$$
Y=1,668+0,423 X_{1}+0,404 X_{2}+0,351 X_{3}
$$

Nilai konstanta (a) sebesar 1,668 memiliki arti bahwa apabila nilai pengetahuan perpajakan $\left(X_{1}\right)$, sanksi pajak $\left(X_{2}\right)$, kesadaran wajib pajak $\left(X_{3}\right)$ bernilai 0 (nol), maka nilai kepatuhan wajib pajak $(Y)$ adalah sebesar 1,668.

Nilai koefisien pengetahuan perpajakan $\left(X_{1}\right)$ sebesar 0,423 menunjukkan bahwa pengetahuan perpajakan $\left(X_{1}\right)$ memiliki hubungan positif pada kepatuhan wajib pajak UMKM. Artinya, jika variabel pengetahuan perpajakan meningkat sebesar satu satuan, maka kepatuhan wajib pajak UMKM akan meningkat sebesar 0,423 satuan dengan asumsi variabel bebas lainnya konstan.

Nilai koefisien sanksi pajak $\left(X_{2}\right)$ 0,404 menunjukkan bahwa sanksi pajak $\left(X_{2}\right)$ memiliki hubungan positif pada kepatuhan wajib pajak UMKM. Artinya, jika variabel sanksi pajak meningkat sebesar satu satuan, maka kepatuhan wajib pajak UMKM akan meningkat sebesar 0,404 satuan dengan asumsi variabel bebas lainnya konstan.

Nilai koefisien kesadaran wajib pajak $\left(X_{3}\right)$ sebesar 0,351 menunjukkan bahwa kesadaran wajib pajak $\left(\mathrm{X}_{3}\right)$ memiliki hubungan positif pada kepatuhan wajib pajak UMKM. Artinya, jika variabel kesadaran wajib pajak meningkat sebesar satu satuan, maka kepatuhan wajib pajak UMKM akan meningkat sebesar 0,351 satuan dengan asumsi variabel bebas lainnya konstan.

Hasil uji F menyatakan signifikan $\mathrm{F}$ atau $\mathrm{P}$ value $<0,05$ maka hubungan antar variabel-variabel bebas adalah signifikan memengaruhi kepatuhan wajib pajak UMKM di KPP Pratama Badung Utara dan model regresi yang digunakan dianggap layak uji. Hasil uji simultan/uji F akan disajikan pada Tabel 5, sebagai berikut. 
Tabel 5. Hasil Uji Kelayakan Model (Uji F)

\begin{tabular}{lccccc}
\hline Model & $\begin{array}{c}\text { Sum of } \\
\text { Squares }\end{array}$ & $d f$ & $\begin{array}{c}\text { Mean } \\
\text { Square }\end{array}$ & F & Sig. \\
\hline Regression & 226.000 & 3 & 75.333 & 17.954 & $.000^{\mathrm{a}}$ \\
Residual & 394.419 & 94 & 4.196 & & \\
Total & 620.418 & 97 & & & \\
\hline
\end{tabular}

Sumber: Data Penelitian, 2019

Berdasarkan Tabel 5, dapat dilihat bahwa signifikan uji F yaitu sebesar 0,000 lebih kecil dari 5\%, sehingga dapat disimpulkan bahwa regresi linear yang diestimasi layak digunakan untuk menjelaskan pengaruh pengetahuan perpajakan, sanksi pajak, dan kesadaran wajib pajak terhadap kepatuhan wajib pajak UMKM.

Koefisien determinasi mengukur seberapa jauh kemampuan variansi variabel independen dalam menerangkan variansi variabel dependen. Pada penelitian ini, koefisin determinasi yang digunakan adalah nilai dari adjusted $R^{2}$ karena apabila suatu variabel ditambahkan ke dalam model dan hasilnya tidak signifikan maka akan mengalami kenaikan yang tidak terlalu tinggi. Hasil uji koefisien determinasi disajikan pada Tabel 6, sebagai berikut.

Tabel 6. Hasil Uji Koefisien Determinasi (Adjusted $R^{2}$ )

\begin{tabular}{lllll}
\hline Model & $\mathrm{R}$ & R Square & Adjusted R Square & $\begin{array}{l}\text { Std. Error of the } \\
\text { Estimate }\end{array}$ \\
\hline 1 & $0.604^{\mathrm{a}}$ & 0.364 & 0.344 & 2.04840 \\
\hline
\end{tabular}

Sumber: Data Penelitian, 2019

Berdasarkan Tabel 6, dapat diketahui nilai dari Adjusted $R$ Square adalah 0,344 atau $34 \%$ ini artinya sebesar $34 \%$ variansi kepatuhan wajib pajak UMKM dipengaruhi oleh variansi pengetahuan perpajakan, sanksi pajak dan kesadaran wajib pajak. Sisanya sebesar $66 \%$ dijelaskan oleh variabel-variabel lain yang tidak dijelaskan dalam penelitian ini.

Di dalam penelitian ini Uji t dilakukan untuk menunjukkan pengaruh semua variabel-variabel independen secara parsial pada variabel dependen. Pengaruh pengetahuan perpajakan, sanksi pajak dan kesadaran wajib pajak secara parsial pada kepatuhan wajib pajak UMKM dapat dilihat dengan membandingkan nilai probabilitas dengan level of significance (a) sebesar 5\%. Penarikan simpulan dilakukan dengan kriteria apabila nilai probabilitas < level of significance $5 \%$, maka pengetahuan perpajakan, sanksi pajak dan kesadaran wajib pajak secara parsial berpengaruh pada kepatuhan wajib pajak UMKM $\left(\mathrm{H}_{0}\right.$ ditolak dan $\mathrm{H}_{1}$ diterima). Sebaliknya, apabila nilai probabilitas > level of significance $5 \%$, maka pengetahuan perpajakan, sanksi pajak dan kesadaran wajib pajak secara parsial tidak berpengaruh pada kepatuhan wajib pajak UMKM $\left(\mathrm{H}_{0}\right.$ diterima dan $\mathrm{H}_{1}$ ditolak). Hasil uji t disajikan pada Tabel 7, sebagai berikut.

Tabel 7. Hasil Uji Hipotesis (Uji t)

\begin{tabular}{lll}
\hline Variabel & T hitung & Sig. uji t \\
\hline (Constant) & 0.651 & 0.517 \\
Pengetahuan Pajak & 4.044 & 0.000 \\
Sanksi Pajak & 3.301 & 0.001 \\
Kesadaran Wajib Pajak & 2.807 & 0.006 \\
\hline
\end{tabular}

Sumber: Data Penelitian, 2019 
Berdasarkan hasil analisis pada Tabel 7, menunjukkan bahwa pengetahuan perpajakan memiliki nilai signifikansi sebesar 0,000 dengan $t_{\text {hitung }}$ sebesar 4,044. Nilai signifikansi 0,000 lebih kecil dari tingkat kesalahan yang dapat diterima yaitu $5 \%$ atau $(0,000)<(0,05)$ mengindikasikan bahwa $\mathrm{H}_{0}$ ditolak dan $\mathrm{H}_{1}$ diterima. Hal ini menunjukkan bahwa semakin tinggi tingkat pengetahuan perpajakan, maka semakin tinggi juga tingkat kepatuhan wajib pajak UMKM.

Berdasarkan hasil analisis pada Tabel 7, menunjukkan bahwa sanksi pajak

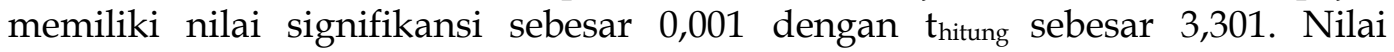
signifikansi 0,001 lebih kecil dari tingkat kesalahan yang dapat diterima yaitu $5 \%$ atau $(0,001)<(0,05)$ mengindikasikan bahwa $\mathrm{H}_{0}$ ditolak dan $\mathrm{H}_{2}$ diterima. Hal ini menunjukkan bahwa semakin tegas sanksi pajak yang diberikan, maka tingkat kepatuhan wajib pajak UMKM akan semakin meningkat.

Berdasarkan hasil analisis pada Tabel 7, menunjukkan bahwa kesadaran wajib pajak memiliki nilai signifikansi sebesar 0,006 dengan $t_{\text {hitung }}$ sebesar 2,807. Nilai signifikansi 0,006 lebih kecil dari tingkat kesalahan yang dapat diterima yaitu $5 \%$ atau $(0,000)<(0,05)$ mengindikasikan bahwa $\mathrm{H}_{0}$ ditolak dan $\mathrm{H}_{3}$ diterima. Hal ini menunjukkan bahwa semakin tinggi tingkat kesadaran wajib pajak, maka semakin tinggi juga tingkat kepatuhan wajib pajak UMKM.

Hipotesis pertama penelitian ini menyatakan bahwa pengetahuan perpajakan berpengaruh positif terhadap kepatuhan wajib pajak orang pribadi sektor UMKM di KPP Pratama Badung Utara. Hasil pengujian dengan menggunakan regresi linear berganda seejalan dengan hipotesis yang dirumuskan yang menunjukkan bahwa pengetahuan perpajakan berpengaruh positif kepada kepatuhan wajib pajak UMKM. Nilai regresi menunjukkan nilai koefisien positif sebesar 0,423 dengan nilai signifikansi 0,000 lebih kecil dari 0,05 $(0,000)<(0,05)$. Nilai koefisien regresi positif menunjukkan hubungan yang searah antara pengetahuan perpajakan dengan kepatuhan wajib pajak UMKM di KPP Pratama Badung Utara.

Hasil ini memiliki arti bahwa semakin tinggi tingkat pengetahuan perpajakan maka tingkat kepatuhan wajib pajak UMKM semakin meningkat pula. Hasil ini mendukung theory of planned behavior terkait keyakinan dari wajib pajak tersebut terhadap sesuatu yang mereka ketahui dapat menghasilkan hal yang positif. Terkait dengan PP no 23 Tahun 2018, wajib pajak yang telah mengetahui peraturan tersebut dapat termotivasi untuk meningkatkan kepatuhan perpajakannya karena peraturan tersebut memberi kemudahan dan keadilan bagi wajib pajak UMKM dalam memenuhi kewajiban perpajakan. Hasil penelitian ini sesuai dengan penelitian (Mintje, 2016) dan (Oladipupo \& Obazee, 2016) yang menunjukkan bahwa pengetahuan perpajakan berpengaruh positif terhadap kepatuhan wajib pajak UMKM.

Hipotesis kedua penelitian ini menyatakan bahwa sanksi pajak berpengaruh positif terhadap kepatuhan wajib pajak orang pribadi sektor UMKM di KPP Pratama Badung Utara. Hasil pengujian dengan menggunakan regresi linear berganda seejalan dengan hipotesis yang dirumuskan yang menunjukkan bahwa sanksi pajak berpengaruh positif terhadap kepatuhan wajib pajak UMKM. Nilai regresi menunjukkan nilai koefisien positif sebesar 0,404 dengan nilai signifikansi 0,000 lebih kecil dari $0,05(0,000)<(0,05)$. Nilai koefisien regresi positif 
menunjukkan hubungan yang searah antara sanksi pajak dengan kepatuhan wajib pajak UMKM di KPP Pratama Badung Utara.

Hasil ini sesuai dengan theory of planned behavior bahwa sanksi pajak merupakan control belief dari wajib pajak tersebut, adanya sanksi pajak yang tegas dapat menumbuhkan niat wajib pajak untuk patuh dalam memenuhi kewajiban perpajakannya. Hasil penelitian ini sejalan dengan penelitian sebelumnya yang dilakukan oleh (Sasmita, 2015), (Cahyani \& Noviari, 2019) dan (Oladipupo \& Obazee, 2016) yang menyatakan bahwa sanksi pajak berpengaruh positif terhadap kepatuhan wajib pajak UMKM.

Hipotesis ketiga penelitian ini menyatakan bahwa kesadaran wajib pajak berpengaruh positif terhadap kepatuhan wajib pajak orang pribadi sektor UMKM di KPP Pratama Badung Utara. Hasil pengujian dengan menggunakan regresi linear berganda seejalan dengan hipotesis yang dirumuskan yang menunjukkan bahwa kesadaran wajib pajak berpengaruh positif terhadap kepatuhan wajib pajak UMKM. Nilai regresi menunjukkan nilai koefisien positif sebesar 0,351 dengan nilai signifikansi 0,000 lebih kecil dari $0,05(0,000)<(0,05)$. Nilai koefisien regresi positif menunjukkan hubungan yang searah antara kesadaran wajib pajak dengan kepatuhan wajib pajak UMKM di KPP Pratama Badung Utara.

Hasil ini sesuai dengan theory of planned behavior bahwa kesadaran wajib pajak merupakan behavioral beliefs, ketika wajib pajak ingin membayar pajak, maka ia memiliki keyakinan mengenai manfaat yang akan diperoleh dari pajak yang dibayarnya. Hasil penelitian ini sesuai dengan penelitian sebelumnya yang dilakukan oleh (Sasmita, 2015) dan (Mintje, 2016) yang menyatakan bahwa terdapat pengaruh secara signifikan dan positif antara kesadaran wajib pajak terhadap kepatuhan wajib pajak.

\section{SIMPULAN}

Penelitian ini menghasilan simpulan mengenai pengaruh pengetahuan perpajakan, sanksi pajak dan kesadaran wajib pajak terhadap kepatuhan wajib pajak orang pribadi sektor UMKM di KPP Pratama Badung Utara. Hasil uji dalam penelitian ini menemukan bahwa variabel independen yaitu pengetahuan perpajakan, sanksi pajak dan kesadaran wajib pajak berpengaruh positif terhadap kepatuhan wajib pajak orang pribadi sektor UMKM. Penelitian ini mendukung theory of planned behavior yaitu kepatuhan wajib pajak dipengaruhi oleh niat wajib pajak itu sendiri dalam mengambil tindakan untuk patuh terhadap kewajiban perpajakan. Penelitian ini dapat digunakan sebagai motivasi bagi instansi pajak untuk dapat meningkatkan sosialisasi terkait pengetahuan perpajakan dan penurunan tarif pajak UMKM, sanksi yang dapat dikenakan oleh wajib pajak UMKM, serta sosialisasi terkait peraturan baru yaitu PP No 23 Tahun 2018. Selain itu KPP Pratama Badung Utara diharapkan dapat memberikan segala informasi yang diperlukan wajib pajak untuk meningkatkan kepatuhan wajib pajak UMKM. Bagi peneliti selanjutnya, penelitian ini diharapkan dapat menjadi bahan rujukan untuk menambah informasi yang diperlukan dan sebagai acuan dalam penelitian yang dilakukan. 


\section{REFERENSI}

Cahyani, L. P. G., \& Noviari, N. (2019). Pengaruh Tarif Pajak, Pemahaman Perpajakan, dan Sanksi Perpajakan Terhadap Kepatuhan Wajib Pajak UMKM. E-Jurnal Akuntansi Universitas Udayana, 26(3), 1885-1911.

Dewinta, R. M. (2012). Pengaruh Persepsi Pelaksanakan Sensus Pajak Nasional dan Kesadaran Perpajakan terhadap Kepatuhan Wajib Pajak di Lingkungan Kantor Wilayah Direktorat Jenderal Pajak Daerah Istimewa Yogyakarta. Skripsi.

Fuadi, A., \& Mangoting, Y. (2013). Pengaruh Kualitas Pelayanan Petugas Pajak, Sanksi Perpajakan dan Biaya Kepatuhan Pajak Terhadap Kepatuhan Wajib Pajak UMKM. TAX \& ACCOUNTING REVIEW, VOL-01.

Imaniati, Z. Z. (2016). Pengaruh Persepsi Wajib Pajak terhadap penerapanan Peraturan Pemerintah Nomor 46 Tahun 2013, Pemahaman Perpajakan dan Sanksi Pajak terhadap Kepatuhan Wajib Pajak UMKM di kota Yogyakarta. Jurnal Akuntansi Universitas Negeri Yogyakarta, V(NO. 2).

Jatmiko, A. N. (2006). Pengaruh Sikap Wajib Pajak pada Pelaksanaan Sanksi Denda, Pelayanan Fiskus dan Kesadaran Perpajakan terdadap Kepatuhan Wajib Pajak. Semarang: Program Studi Magister Akuntansi Program Pascasarjana Universitas Diponegoro.

Julianti, M. (2014). Analisis Faktor-Faktor yang Mempengaruhi Kepatuhan Wajib Pajak Orang Pribadi Untuk Membayar Pajak Dengan Kondisi Keuangan dan Preferensi Risiko Wajib Pajak Sebagai Variabel Moderating. Skripsi FEB Universitas Diponogoro.

Julianto, A. (2016). Pengaruh Tarif, Sosialisasi Serta Pemahaman Perpajakan Terhadap Kepatuhan Wajib Pajak Umkm Di Kota Semarang. Jurnal Akuntansi Dan Bisnis, (Universitas Dian Nuswantoro Semarang).

Lazuardini, E. R., \& Susyanti, H. J. (2018). Pengaruh Pemahaman Peraturan Perpajakan, Tarif Pajak Dan Sanksi Pajak Terhadap Kepatuhan Wajib Pajak Umkm (Studi Pada Wajib Pajak Orang Pribadi Yang Terdaftar Di Kpp Pratama Malang Selatan). Artikel Ilmiah UIM, 25-34.

Masruroh, S., \& Zulaikha. (2013). Pengaruh Kemanfaaatan NPWP, Pemahaman Wajib Pajak, Kualitas Pelayanan, Sanksi Perpajakan Terhadap Kepatuhan Wajib Pajak (Studi Empiris Pada WPOP Di Kabupaten Tegal). Diponegoro Journal Of Accounting, VOL 2, Number 4.

Mintje, M. S. (2016). Pengaruh Sikap, Kesadaran, dan Pengetahuan Terhadap Kepatuhan Wajib Pajak Orang Pribadi Pemilik (UMKM) Dalam Memiliki (NPWP) Studi Pada Wajib Pajak Orang Pribadi Pemilik UMKM Yang Terdaftar di KPP Pratama Manado. Jurnal EMBA, VOL 4, No., Hal. 1031-1043.

Muliari, N. K., \& Setiawan, P. E. (2011). Pengaruh Persepsi Tentang Sanksi Perpajakan Dan Kesadaran Wajib Pajak Pada Kepatuhan Pelaporan Wajib Pajak Orang Pribadi Di Kantor Pelayanan Pajak Pratama Denpasar Timur. Jurnal Akuntansi Universitas Udayana, Vol.6.1, pages 1-23.

Oladipupo, A. O., \& Obazee, U. (2016). Tax Knowledge, Penalties, and Tax Complience in Small and Medium Scale Enterprise in Nigeria. Nigeria: University of Benin.

Sasmita, S. N. A. (2015). Pengaruh Pemahaman Wajib Pajak, Pelayanan Fiskus, Kesadaran Wajib Pajak Dan Sanksi Perpajakan Terhadap Kepatuhan Wajib 
Pajak Pemilik Usaha Kecil Menengah Dalam Pelaporan Kewajiban Perpajakan Di Semarang (Studi UMKM Di Kota Semarang). Artikel Ilmiah, (Semarang: Fakultas Ekonomi dan Bisnis Universitas Diponegoro).

Supadmi, N. L. (2010). Meningkatkan Kepatuhan Wajib Pajak melalui Kualitas Pelayanan. Jurnal Akuntansi Dan Bisnis, (Fakultas Ekonomi Universitas Udayana).

Wiranatha, H., \& Rasmini, N. K. (2017). Pengaruh Pengetahuan Perpajakan, Modernisasi Sistem Administrasi Perpajakan, Tax Amnesty, Tingkat Penghasilan Pada Kepatuhan Wajib Pajak. E-Jurnal Akuntansi Universitas Udayana, Vol.21(3), 2395-2424.

Yadnyana, I. K. (2009). Pengaruh Moral dan Sikap Wajib Pajak pada Kepatuhan Wajib Pajak Koperasi di Kota Denpasar. Buletin Studi Ekonomi, (Denpasar: Fakultas Ekonomi Dan Bisnis).

Yusro, H. W. (2014). Pengaruh Tarif Pajak, Mekanisme Pembayaran Pajak dan Kesadaran Membayar Pajak Terhadap Kepatuhan Wajib Pajak UMKM di Kabupaten Jepara. Accounting Analysis Journal, VOL.3(4). 